
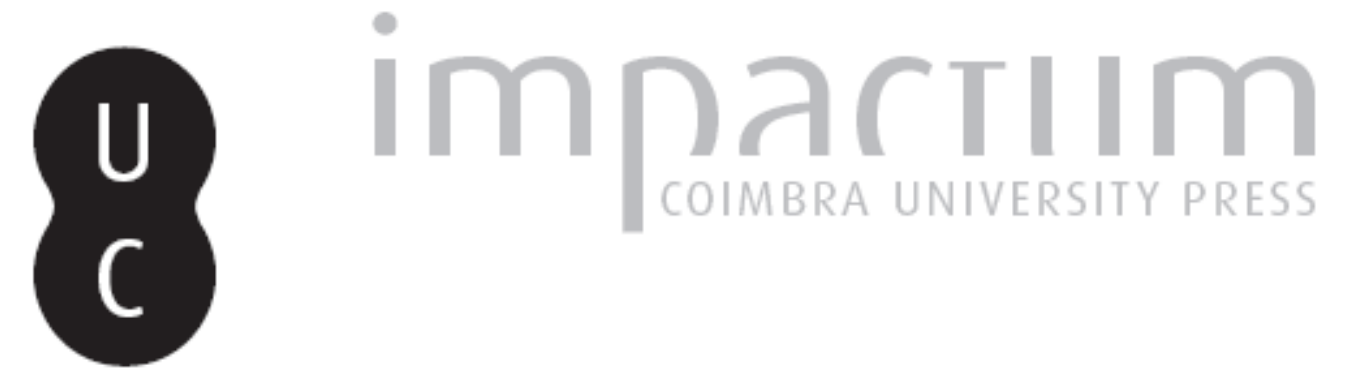

\title{
A Faculdade de Letras de Coimbra: uma escola universitária na República
}

Autor(es): $\quad$ Torgal, Luís Reis

Publicado por: Faculdade de Letras da Universidade de Coimbra

URL persistente:

URI:http://hdl.handle.net/10316.2/32380

DOI:

DOI:http://dx.doi.org/10.14195/0870-4112_9_2

Accessed : $\quad$ 26-Apr-2023 09:22:29

A navegação consulta e descarregamento dos títulos inseridos nas Bibliotecas Digitais UC Digitalis, UC Pombalina e UC Impactum, pressupõem a aceitação plena e sem reservas dos Termos e Condições de Uso destas Bibliotecas Digitais, disponíveis em https://digitalis.uc.pt/pt-pt/termos.

Conforme exposto nos referidos Termos e Condições de Uso, o descarregamento de títulos de acesso restrito requer uma licença válida de autorização devendo o utilizador aceder ao(s) documento(s) a partir de um endereço de IP da instituição detentora da supramencionada licença.

Ao utilizador é apenas permitido o descarregamento para uso pessoal, pelo que o emprego do(s) título(s) descarregado(s) para outro fim, designadamente comercial, carece de autorização do respetivo autor ou editor da obra.

Na medida em que todas as obras da UC Digitalis se encontram protegidas pelo Código do Direito de Autor e Direitos Conexos e demais legislação aplicável, toda a cópia, parcial ou total, deste documento, nos casos em que é legalmente admitida, deverá conter ou fazer-se acompanhar por este aviso.

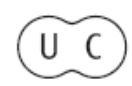



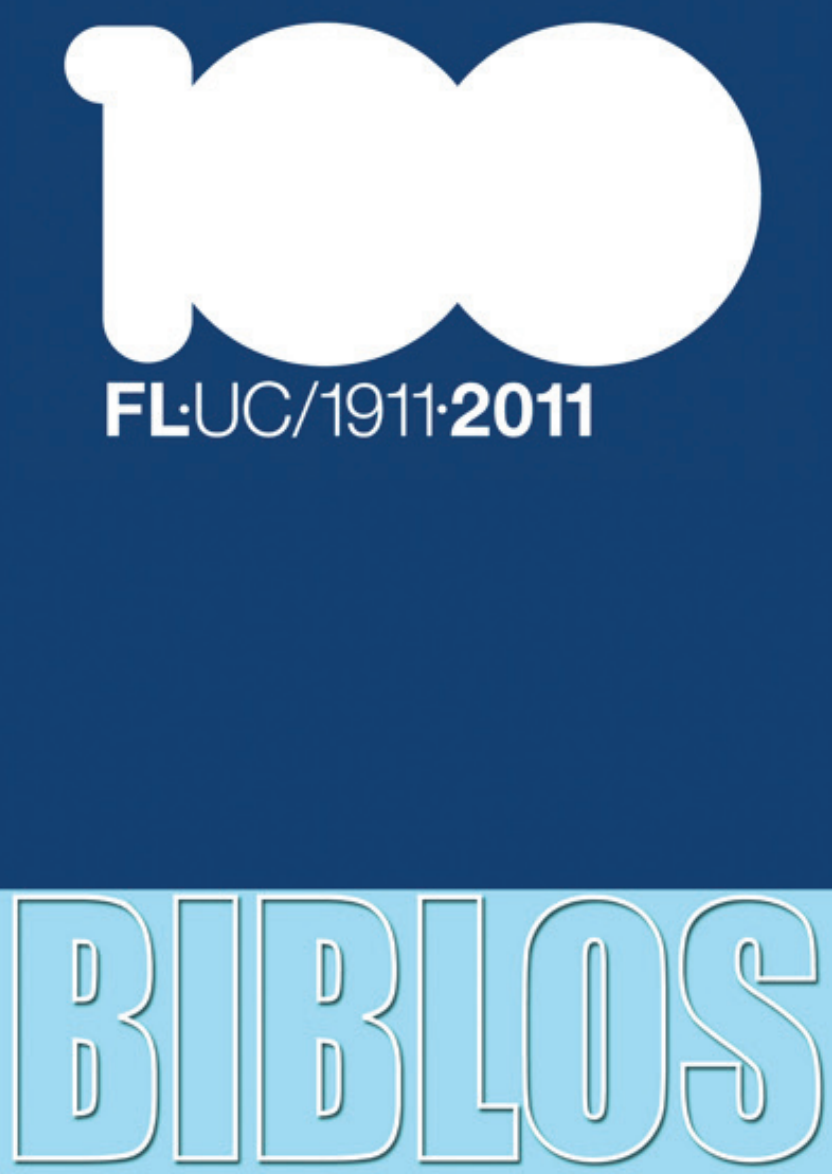

REVISTA DA FACULDADE DE LETRAS UNIVERSIDADE DE COIMBRA 
Biblos, n. s. IX (2011) 33-69

Luís ReIS ToRgaL

Universidade de Coimbra

\title{
A FACULDADE DE LETRAS DE COIMBRA UMA ESCOLA UNIVERSITÁRIA NA REPÚBLICA
}

\section{Resumo}

A Faculdade de Letras da Universidade de Coimbra é uma escola de criação republicana (1911), que poderá ter as suas origens longínquas na medieval Faculdade de Artes, mas que foi marcada por alguns traços simbólicos da Faculdade de Teologia. Esta relação, num tempo de expressão laicista, marcou a sua representação no mundo político, provocando, em 1919, uma tentativa - aliás frustrada - de a extinguir, sob a acusação de ser uma escola "escolástica". Foi, porém, a Faculdade de Letras que mais contribuiu para a renovação e refundação dos rituais académicos, de origem eclesiástica. Mas também pertenceu à Faculdade de Letras a primeira mulher professora universitária e foi a escola frequentada por mais mulheres. Esse facto não a apresenta, no entanto, como uma escola de luta pela emancipação feminina e pelo sufragismo.

Palavras-Chave: Letras, Universidade, Artes, Teologia, Rituais académicos, Mulher, República, Laicismo.

\begin{abstract}
The Faculty of Arts and Humanities at the University of Coimbra is a school of Republican creation (1911). Its remote roots may lie in the medieval Faculty of Arts, but it was marked by symbolic traces of the Faculty of Theology. This relationship, at a time of secular trends, influenced its representation in the political world, leading to a (failed) attempt at extinguishing it in 1919, on the grounds of being a "scholastic" school. It was, however, the Faculty of Arts and Humanities that most contributed to the renewal and re-establishment of the academic rituals of ecclesiastical origin. It was also here that, for the first time, a woman became a university professor, and it was the institution with the highest number of female students. However, this did not mean that the Faculty fought for the emancipation of women and for female suffrage.
\end{abstract}

Keywords: Humanities, University, Arts, Theology, Academic Rituals, Woman, Republic, Secularism.

\footnotetext{
* Professor aposentado.
} 


\section{Faculdade de Letras, as suas origens remotas e as suas contradições: "laico" versus "sagrado"}

As origens remotas das Faculdades de Letras estão, obviamente, como é sabido, nas Faculdades de Artes das Universidades medievais. De resto, a expressão Arts - Faculty of Arts, ainda se utiliza na designação anglo-saxónica.

Em Portugal, a Faculdade de Artes já nos aparece na composição dos saberes da Universidade fundada em Lisboa, cujo documento data de 1 de Março de 1328 (da era de César ou era hispânica), ou seja, 1290 da era de Cristo. Mas a palavra "artes" tem uma acepção mais ampla, pois esse mesmo documento régio - não se referindo concretamente às faculdades (ao invés da bula de Nicolau IV, de 9 de Agosto do terceiro ano do seu pontificado, isto é 1290) - fala da "provisão" do Studium Generale com "Doutores em todas as Artes", ou seja, na Universidade passavam a ensinar-se "saberes" em todas as "faculdades lícitas", com excepção provável da Teologia. É assim que a Universidade - depois verdadeira Universitas, no sentido de "corporação" - passa para Coimbra em 1308, sendo-lhe então concedida a Magna Charta Privilegiorum (1309), onde se refere que os estudos de Teologia eram ministrados nos "conventos religiosos dos Frades Pregadores e dos Menores", o que nos leva a perguntar se as "artes teológicas" já faziam então parte dos estudos universitários, se bem que estudadas nos conventos mendicantes. Quando se dá a transferência definitiva desta nossa Universidade migrante, em 1537, altura em que se verifica a mudança definitiva para Coimbra e para o Palácio Real, a Faculdade de Artes estava também a dar os seus últimos passos, pois em breve se transformava, em 1548, num colégio que acolheu grandes humanistas portugueses e estrangeiros.

Os jesuítas, com a Contra-Reforma, vieram a orientar o Colégio das Artes, sensivelmente ao mesmo tempo que era criada, em 1559, a Universidade de Évora, a segunda universidade do país, até dois séculos depois, precisamente em 1759, em que essa Universidade foi abolida, com a expulsão pelo Marquês de Pombal ou por D. José da Companhia de Jesus, que também abandonou o referido Colégio. Transformado em escola vestibular por excelência para a entrada na Universidade, veio dar lugar, depois de 1836, ao Liceu de Coimbra, que passou a funcionar no mesmo local. 
Curiosamente, no lugar das primeiras instalações do Colégio das Artes e onde viria a funcionar a Inquisição, veio a formar-se há alguns anos o Centro de Artes Visuais; o local onde a seguir se fixou o Colégio das Artes, junto do Colégio de S. Jerónimo, depois ocupado pelo Liceu e a seguir pelo Hospital da Universidade, tornou-se as instalações do Departamento de Arquitectura da FCTUC. Recentemente, com confirmação pelos novos Estatutos da Universidade de Coimbra, aprovados ministerialmente em 21 de Agosto de 2008, ressurgiu a designação de "Colégio das Artes", mas agora entendido como "Escola de Estudos Avançados", que procura dar "coesão institucional à reflexão científica nos domínios artísticos" e procura desenvolver "o espírito criativo, em diálogo permanente com o conjunto dos saberes cultivados nas várias Faculdades". Ou seja, agora as "artes" têm o sentido das artes plásticas (Fine Arts), da representação e da imagem, depois de terem assumido durante muito tempo o sentido das artes do trivium e do quadrivium, estas ligadas às ciências naturais e exactas e aquelas às artes da gramática, da retórica e da dialéctica, o que consideraríamos hoje as "letras", no sentido de língua e literatura, de arte de falar e de arte de pensar, ou seja, da Lógica ou, por alargamento, da Filosofia, termo que, afinal, teve, depois da Reforma Pombalina, um sentido mais "científico" (na acepção de Science, em inglês), com a criação da Faculdade de Filosofia ("Filosofia Natural" - Física, Química, Zoologia, Mineralogia, Botânica).

No fim de contas, as "artes liberais", como saberes, contrapuseramse durante os tempos medievais e modernos às "artes servis" (resultantes da força do trabalho manual, que só muito lentamente se foram libertando desta designação pejorativa). Além disso, pode dizer-se que as artes ficaram envolvidas durante séculos pela ideologia da Igreja, numa concepção de humanismo cristão e de humanismo católico (em sentido contra-reformista em países, como o nosso, com pequena ou nenhuma presença protestante), até que começaram o seu lento ciclo de secularização (contra as ordens religiosas, mesmo contra as congregações seculares, como os padres jesuítas) e de laicização. E, na verdade, os liceus, fundados pelo liberalismo avançado, setembrista, de Passos Manuel, em 1836, acabaram por se laicizar mais rapidamente do que os estudos primários e universitários, conforme alegava Sidónio Pais na sua oração de Sapientia de Outubro de 1908. 


\section{O liberalismo, o "conflito de faculdades" e as "Faculdades de Letras"}

Com efeito, só o vintismo, afinal o primeiro liberalismo avançado em Portugal, do efémero triénio liberal (1820-1823), vai experimentar, na sequência do Iluminismo pombalino e no contexto do que poderemos chamar, à maneira kantiana, o "conflito de faculdades"" (em que se revelaram afinal os "cientistas", nacionais ou "estrangeirados"), as primeiras propostas de criação das faculdades de Letras. Os defensores destas propostas comungavam da ideia de que era necessário neutralizar a força secular de ambos os direitos (Leis e Cânones, estes com menor importância depois da reforma de 1772 do Marquês de Pombal) e da Teologia, opondo-lhes não só estudos de ciências exactas e naturais, mas também novos estudos humanísticos e filosóficos, afastados da sua tradicional ligação à Igreja.

O estudante e bacharel de Medicina José Pinto Rebelo de Carvalho, redactor do jornal $O$ Censor Provinciano, alinha nas ideias radicais da Convenção, defendendo a abolição da Universidade de Coimbra e a instauração de escolas autónomas. Daí que utilize, a par do tradicional termo "Faculdade", o termo mais genérico de "Escola". A sua afirmação básica é de grande evidência revolucionária:

A Universidade não deve ser reformada, precisa de ser abolida, e tratar-se quanto antes da organização de Escolas Centrais, independentes umas das outras, onde se ensinem as Ciências, Artes e as Letras, debaixo dum plano adequado ao Sistema Constitucional e livre de todo o aparato fradesco, ou monacal, que faz a base desta Gótica Instituição. ${ }^{2}$

No periódico referido, Rebelo de Carvalho defende ainda, entre essas "Escolas Centrais", a criação de "uma Faculdade de Letras". Trata-se, porém, de uma faculdade sui generis, pois seria, simultaneamente, uma faculdade vestibular ou preparatória e uma faculdade profissional, uma faculdade literária e linguística e científica. Assim, ensinar-se-iam ali as línguas antigas e modernas e a literatura portuguesa e estrangeira, ao mesmo tempo que "ciências físicas e matemáticas". Seria necessária a frequência desta faculdade durante quatro anos com

\footnotetext{
${ }^{1}$ E. Kant, Der Streit der Fakultäten, 1798.

${ }^{2}$ O Censor Provinciano, n. . 8, 25.1.1923, p. 122.
} 
aproveitamento para seguir depois as Escolas de Ciências Naturais (resultantes da fusão de Matemática e Filosofia), de Medicina e de Direito. Mas também deveria haver um curso especial para que "os indivíduos que não quiserem frequentar outras Escolas científicas tomem ideias bastantes para depois poderem aplicar-se ao estudo das Ciências naturais, da Agricultura, das Artes, etc.”.

Verdadeiramente a primeira proposta de uma Faculdade de Letras tal como a conhecemos foi, porém, apresentada por outro cientista, químico e físico de formação, que frequentou o Institut de Paris e chegou, pelo menos, a deslocar-se à Suíça em viagem científica - Luís Mouzinho de Albuquerque ${ }^{3}$. Foi, de resto, de França que enviou para as Cortes liberais o seu projecto, a que chamou Ideias sobre o estabelecimento da Instrução Pública.

Como Rebelo de Carvalho, mas de modo diferente, entende que o conceito de "Universidade", e provavelmente de Faculdade, deveria ser alterado, criando-se "Academias" em Lisboa, Porto e Coimbra. Nessas Academias existiriam Faculdades (continua, apesar de tudo, a usar o conceito) de Ciências Exactas, de Ciências Naturais, de Medicina, de Direito e de Letras. As Faculdades de Letras Sagradas ou de Teologia deveriam recolher aos seminários. Nas Faculdades de Letras haveria sete cadeiras: Eloquência e Poesia, Literatura Antiga, Literatura Moderna Estrangeira, Literatura Nacional, História Geral, História Portuguesa e Filosofia Antiga e Moderna. Além das faculdades, deveriam existir nas Academias de Lisboa e do Porto cadeiras anexas de Economia Política e Industrial, Economia Rural, Navegação e Princípios de Manobra Naval, Arquitectura Naval, Arquitectura Civil e Desenho. $\mathrm{Na}$ Academia de Coimbra, não ligada às artes náuticas, apenas deveriam funcionar as cadeiras de Economia Política e Industrial, Economia Rural, Arquitectura Civil e Desenho. Portanto, as faculdades de Letras, tal como as imaginava Luís Mouzinho de Albuquerque, deveriam ter uma estrutura disciplinar literária, histórica e filosófica, não faltando nas Academias, incluindo em Coimbra, o ensino da Economia e das Belas Artes.

Mas, não ficaram pelo vintismo os projectos de criação de faculdades de Letras. José Maria de Abreu, lente de Filosofia da Universidade de

${ }^{3}$ Ver Magda Pinheiro, Luís Mouzinho de Albuquerque. Um intelectual na Revolução, Lisboa, Quetzal, 1992. 
Coimbra, que ensinou várias cadeiras, algumas de sentido prático, tais como Economia Rural, Veterinária e Tecnologia, e Agricultura, a quem se deve uma importante compilação de Legislação Académica e que foi Director-Geral da Instrução Pública de 1859 a 1861 e de 1869 a 1870, desempenhando também outros altos cargos no domínio do ensino, apresentou igualmente uma proposta de criação. Fê-lo em 1857, assim como em 1874 a apresentou António José Teixeira, professor de Matemática, também na Universidade de Coimbra. No entanto, em qualquer das situações, não se passou de propostas inconsequentes.

Seja como for, vale a pena sublinhar o sentido da crítica às reformas da Instrução Pública apresentadas pelo conimbricense José Maria de Abreu num artigo publicado em $O$ Instituto (vol. 6) e intitulado "A Reforma do Ensino Público em Portugal", onde fez a aludida proposta. Essa crítica refere-se a uma tendência que se tornou crónica em Portugal, ou seja, a passagem para o nível "universitário" de "cursos politécnicos", que perderam a sua especificidade e não ganharam em originalidade. Ao ouvir as palavras do lente de Filosofia (natural), parece que estamos a ouvir algumas críticas aos actuais Institutos Politécnicos (por vezes fundados apenas para corresponder a reivindicações regionalistas), os quais, em vez de aprofundarem o seu sentido de escolas práticas, se quiseram transformar em "quase universidades", sem o correspondente aprofundamento científico. Vejamos, pois, as palavras de José Maria de Abreu

As diversas reformas desde 1836, criando sucessivamente novos estabelecimentos de instrução superior com demasiada largueza, e pouca discrição, deram lugar a deploráveis rivalidades de algumas dessas escolas, que disputavam primazia às mais antigas, e que buscaram por isso desde logo equiparar-se em tudo a elas, afastando-se assim, com grave quebra do ensino, do fim primitivo de suas instituições e esquecendo um pouco a sua elevada e importantíssima missão no estado das ciências! A escola quis converter-se em faculdade. A pretensão dos graus académicos tornou-se uma questão de «palpitante interesse» para os que miravam só em suplantar as antigas instituições. A prática foi sacrificada em grande parte às elevadas teorias da ciência; e a universidade, que pelo prestígio da sua existência secular [...], ocupava o primeiro lugar [...], tornou-se por isso mesmo o alvo, a que mais certeiros se dirigiam os tiros dos seus adversários [...]. Foi com este intuito, que em vez de se reformarem as 
escolas médico-cirúrgicas, tornando-as verdadeiras escolas práticas de cirurgia, se lhes aumentaram as cadeiras de medicina, para equiparar aquelas escolas à faculdade de medicina da universidade, deixando em completo abandono a cirurgia e a medicina ministrante. Foi com esse fim que se criaram na escola politécnica quase as mesmas cadeiras que nas faculdades de matemática e filosofia, e que por uma singular contradição se concedeu à escola politécnica o exclusivo da habilitação dos alunos, que se destinavam às armas científicas, com ofensa dos direitos e habilitações dos filhos daquelas faculdades.

Portanto, poderá dizer-se que - para além do conceito da "universidade napoleónica", que se cruza afinal com a ideia da "universidade iluminista" ou "pombalina", de universidade estatal, central e directora dos vários sectores da "instrução pública" - se perfilam três grandes tendências no que toca à visão político-institucional do ensino superior: uma que pretende extinguir pura e simplesmente a Universidade, propondo, à maneira da Convenção francesa, a criação de escolas autónomas; outra que se aproxima da lógica binária ainda hoje existente, de modo diferente, com toda a sua ambiguidade, ou seja, que pretendia que existissem a Universidade e as "Escolas Politécnicas", de sentido mais prático; e outra, finalmente, que conduziria a uma igualização da Universidade e das "Escolas Politécnicas", sem distinção essencial.

Voltando às Faculdades de Letras, e antes da sua criação, surge uma outra linha de inspiração vinda de outro pólo diferente dos "cientistas". Trata-se dos teólogos. Se a Faculdade de Teologia ia tendo cada vez menor significado no contexto da universidade, tomava posição contra as novas correntes filosóficas do tempo - o idealismo, o positivismo, o cientismo, o materialismo, o socialismo -, ao mesmo tempo que se ia adaptando, na medida do possível, à realidade científico-política liberal, pelo menos pela via do regalismo. Daí, por um lado, a sua marca de conservadorismo ideológico, que há-de influenciar as concepções "tradicionalistas" do século XX, e, por outro, as discussões que mantinha com a hierarquia da Igreja, fazendo crer que se afastava da linha eclesiástica fundamental, que se deveria afirmar pela sua independência em relação ao Estado. No contexto destes problemas, parecia evidente aos professores-teólogos que a Faculdade de Teologia se deveria transformar numa outra faculdade. 
Assim, no conturbado ano da greve académica, 1907, a própria Faculdade de Teologia, no seu Conselho, falava da necessidade de reformas, vindo mesmo a pedir, tendo em conta (no seu dizer) que a sua "missão social e religiosa" tinha "atingido o seu termo", a sua transformação numa Faculdade de Letras".

\section{O Curso Superior de Letras}

Só, todavia, em meados do século XIX, no tempo do rei D. Pedro V, se formou a primeira "faculdade de Letras" (embora não tivesse essa designação), não na Universidade de Coimbra, a única existente, mas em Lisboa, na lógica, neste caso só aparentemente convencionista, que se deveriam formar escolas autónomas. Dissemos "aparentemente convencionista" pelo facto de, no caso do Curso Superior de Letras, nos parecer que a intenção da sua criação foi mais inspirada nas Academias do que propriamente em "escolas superiores" independentes da Universidade, pelo que a influência universitária parece ter estado também presente.

Deve salientar-se, na verdade, como nota particular, o empenhamento pessoal do próprio rei, como expressão da sua vocação de monarca intelectual, para quem a história, a literatura e a filosofia tinham uma importância significativa. Por isso, o primeiro passo para a fundação do curso, a que o monarca parecia querer dar a importância de uma "faculdade" (termo que se mantinha, contudo, como termo nobre), foi dado pelo decreto de 30 de Outubro de 1858, expedido pela Vedoria da Casa Real. Criavam-se, assim, três cadeiras, de História, de Literatura Antiga e de Literatura Moderna, especialmente portuguesa. Aliás, D. Pedro, em carta ao ministro da Fazenda, António José de Ávila, do dia 31, dizia: "A Faculdade de Letras aí a deixo esboçada, incompleta, é verdade, mas tal já não são capazes de deixar de ma completar"s.

${ }^{4}$ A.U.C.,Actas do Conselho da Faculdade de Teologia.1901-1912, fls.55-58v. Sobre esta questão, vide J. Ferreira Gomes, A Universidade de Coimbra durante a Primeira República. 1910-1926, Lisboa, Instituto de Inovação Educacional, 1990, cap. I, pp. 18-20.

${ }^{5}$ In Manuel Busquets de Aguilar, O Curso Superior de Letras. 1858-1911, Lisboa, 1939, p. 10. 
Em 14 de Setembro de 1859, aparece finalmente regulamentado o Curso, que foi criado por carta de lei de 8 de Junho anterior. Juntavam-se às referidas cadeiras mais duas, uma de História e outra de Filosofia. Assim, completava-se o quadro de cinco cadeiras que o compunham, ou seja, de acordo com a ordem do decreto e com a terminologia oficial: "História pátria e universal", "Literatura latina e grega e introdução sobre as suas origens", "Literatura moderna da Europa, e especialmente a literatura portuguesa", "Filosofia", e "História universal filosófica". Depois surgiram outras reestruturações, de que se destaca a de 1878 , ficando o curso então organizado da seguinte forma:

$\mathbf{1}^{\mathbf{0}}$. ano: História universal e pátria

Língua e literatura sânscrita, védica e clássica

Filologia comparada

$2^{\circ}$. ano: Literatura grega e latina

Literatura moderna, especialmente a portuguesa

$\mathbf{3}^{\mathbf{0}}$ ano Filosofia

História universal filosófica

Depois, seguiram-se vários projectos de reformas mais profundas, mas não tiveram consecução, só vindo a realizar-se uma reforma significativa em 1901.

Há que salientar, de resto, que o Curso, ligado à Academia das Ciências e funcionando no seu edifício, nunca conseguiu uma estruturação que lhe desse o cariz de uma verdadeira "escola normal", preparadora de professores na área de Letras, o que só veio a suceder quando se transformou numa faculdade, em 1911. Pelo menos numa primeira fase, o seu funcionamento lembrava mais uma sessão académica do que uma verdadeira escola. No ano da abertura, em 1861, Júlio de Castilho, que começou a frequentar as suas aulas, descreve assim o seu espaço escolar de modo pitoresco:

Para lá da teia, as cadeiras dos discípulos, e os lugares privativos dos sócios da Academia Real das Ciências. Ao topo da sala, sobre um estrado alto, a mesa do professor, com alguns livros e o indispensável copo de água. À direita do professor, uma espécie de trono forrado de damasco carmesim, 
onde vinha sentar-se quase todas as noites, ouvindo, aprendendo (e ensinando, sem o suspeitar), o fundador do Curso, o melancólico soberano, o simpático D. Pedro, quase imberbe, pensativo, encostado aos copos da espada, tão singelo e tão grande! ${ }^{6}$

O curso viria, porém, a ter - apesar desta vida irregular e deste sentido inacabado que o caracterizou - um grande significado cultural, pela importância de alguns dos seus mestres e pelas matérias que sabemos terem sido nele ministradas ou que foram objecto de provas para concurso.

A ele estiveram ligados Rebelo da Silva, António José Viale, António Pedro Lopes de Mendonça, José da Silva Mendes Leal, Levi Maria Jordão, Jaime Vasconcelos Abreu, Augusto Seromenho, Teófilo Braga, Adolfo Coelho, Consiglieri Pedroso, Jaime Moniz. E outros, como Herculano e Castilho, não aceitaram, por razões pessoais, integrar o corpo docente. Portanto, facilmente se divisa, neste conjunto de intelectuais de variada formação, historiadores, filólogos, pedagogos e homens integrados nas ideias republicanas e positivistas que escandalizaram o país com as novas teses políticas e culturais. A cultura, apesar de tudo, tinha uma certa dinâmica no fim do Portugal liberal, que passava para o campo da Instrução Pública nos seus vários níveis.

\section{A Faculdade de Letras de Coimbra, escola centenária}

Falemos agora, finalmente, das Faculdades de Letras, e da Faculdade de Letras de Coimbra em especial, que, com a de Lisboa, mas mais do que a de Lisboa, cumpre agora o seu primeiro centenário. Devemos dizer que, para além das pesquisas originais que fizemos - sobretudo tendo em vista que as Faculdades de Letras foram criadas pelo Ministério do Interior, cuja pasta pertencia a António José de Almeida, cuja biografia estudámos $^{7}-$, é fundamental a leitura do livro de Joaquim Ferreira

${ }^{6}$ Lisboa antiga, vol. XI, Lisboa, 1938, 2a . ed., p. 36.

7 António José de Almeida e a República, Lisboa, Círculo de Leitores 2004 (2. edição: Lisboa, Temas e Debates, 2005). 
Gomes sobre a Universidade e a República ${ }^{8}$, embora seja apenas composto (e se apresente como tal) por "Alguns Apontamentos", e da obra sobre os professores da Universidade de Coimbra, entre os quais os da Faculdade de Letras, dirigida por Manuel Augusto Rodrigues?

A República, como é sabido, procurou levar a efeito um amplo programa de reformas da Instrução Pública, a começar no ensino primário e a terminar no ensino superior, tendo também em vista uma completa laicização do ensino, na sequência do que já se fizera (só em parte) no liberalismo. De resto, as orações de Sapientia dos lentes republicanos e "cientistas" de formação, proferidas nos anos anteriores a 1910 (Bernardino Machado, de Filosofia, 1904; Sobral Cid, de Medicina, 1907, Sidónio Pais, de Matemática, 1908, e Eusébio Tamagnini, de Filosofia, 1909, este que, todavia, haveria de se tornar nacional-sindicalista e ministro de Salazar), apontavam, mais ou menos, nesse sentido. Assim, entende-se que, no seio do Governo Provisório, o ministro do Interior (com amplos poderes, incluindo a Instrução Pública), António José de Almeida, médico, que havia formulado críticas ao ensino universitário e ao seu espírito "corporativo", nomeadamente das Faculdades de Medicina ${ }^{10}$ e de Direito ${ }^{11}$, Afonso Costa, ministro da Justiça, e Brito Camacho, ministro da Fazenda, tivessem posto em prática medidas significativas.

Logo em 18 de Outubro de 1910, por decreto do Ministério da Justiça, são abolidos os juramentos religiosos. Através de quatro decretos de 23 e 24 de Outubro, o Ministério do Interior confirmou a abolição, "para todo o sempre", dos referidos juramentos; anulou as matrículas efectuadas no $1 .^{\circ}$ ano da Faculdade de Teologia; considerou "livres" os cursos de todas as cadeiras das diversas faculdades; e tornou facultativo o uso da "capa e batina", ao mesmo tempo que abolia o que restava do "foro académico", passando para a justiça ordinária o julgamento de todas as questões surgidas na Universidade. Entretanto

${ }^{8}$ A Universidade de Coimbra durante a Primeira República (1910-1926). Alguns apontamentos, Lisboa, Instituto de Inovação Educacional, 1990.

${ }^{9}$ Memoria Professorum Universitatis Conimbrigensis, vol. II, 1772-1937. Coimbra, Arquivo da Universidade, 1992, pp. 53-85.

${ }^{10}$ Desaffronta. Historia d'uma perseguição, Coimbra, Livraria Moderna de A. d'Oliveira, 1895 (2. edição: 1896).

${ }^{11}$ Cfr. Discursos de 5 e 9 de Abril de 1907, in Diario da Camara dos Senhores Deputados. 
Brito Camacho irá criar, com base no Instituto Industrial e Comercial de Lisboa, o Instituto Superior Técnico e o Instituto Superior de Comércio.

Manuel de Arriaga, o primeiro reitor nomeado, por António José de Almeida, em 19 de Outubro, vai também solicitar ao governo outras medidas nesse sentido. Curiosa é uma proposta dirigida ao Governo Provisório que o reitor apresentou nos conselhos das faculdades, na qual se destacam a supressão dos "ofícios divinos e todo o mais cerimonial religioso e civil que precedia e acompanhava a imposição dos graus académicos" e a alteração da insígnia da Universidade, da qual se expurgaria "a imagem da Minerva clássica da Grécia da excrescência com que foi adulterada, tirando-lhe da cabeça a coroa real que lhe puseram e do ceptro a cruz que encima", passando a ter a legenda "A Ciência leva a toda a parte a Verdade e, com esta, a Liberdade, o Progresso e a Paz dos Povos".

São, pois, propostas que se integram na conjuntura revolucionária da época, por vezes com alguns ingénuos excessos. Mas, mais importante é o facto de, em 19 de Abril de 1911, terem surgido do Ministério do Interior as "Bases da nova Constituição Universitária". Confirmava-se então a criação das novas Universidades de Lisboa e do Porto (fundadas por decreto de 22 de Março), e surgiam as novas Faculdades de Letras, em Lisboa e em Coimbra, a primeira não inteiramente nova, pois provinha do Curso Superior de Letras, assim como eram criadas em Lisboa e em Coimbra as Escolas Normais Superiores anexas às Faculdades de Letras e de Ciências. Pouco depois, em 9 de Maio, era estabelecido o "Plano de Estudos das Faculdades de Letras das Universidades de Coimbra e de Lisboa". Seriam formadas pelos seguintes grupos: $1 .^{\circ}$ Filologia Clássica; $2 .^{\circ}$ Filologia Românica; $3 .^{\circ}$ Filologia Germânica; $4 .^{\circ}$ História; 5..$^{\circ}$ Geografia; 6. ${ }^{\circ}$ Filosofia. Estes seis grupos originariam cursos em

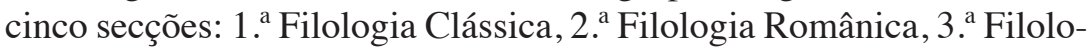
gia Germânica, 4. ${ }^{a}$ Ciências Histórico-Geográficas, e 5. ${ }^{a}$ Filosofia. Em 1914 houve algumas alterações pouco significativas. Em 1930, já durante a Ditadura Militar, verificou-se nova reforma, reduzindo-se as anteriores secções a duas - 1. a secção, Ciências Filológicas, com três grupos, respectivamente, Filologia Clássica, Filologia Românica e Filologia Germânica, que corresponderiam aos três cursos, e 2. ${ }^{\text {a }}$ secção, Ciências Históricas, Geográficas e Filosóficas, com os três grupos, correspondentes a dois cursos de licenciatura, Ciências Histórico-Filosóficas e Ciências Geográficas - e acrescentando-se uma 
outra secção de Cadeiras Anexas (Estética e História da Arte e Estudos Brasileiros e, facultativas, História da Música e Língua Hebraica, na Faculdade de Letras de Coimbra, sendo na Faculdade de Letras de Lisboa as mesmas cadeiras de Estética e História da Arte e Estudos Brasileiros, e ainda de Estudos Camonianos, sendo facultativas, para além de História da Música, Língua Árabe e Sânscrito).

Vale a pena salientar, antes de nos debruçarmos brevemente sobre alguns aspectos das Faculdades de Letras, que as Universidades de Lisboa e do Porto não eram de facto inteiramente novas, pois as suas faculdades provinham de antigas escolas de ensino superior já existentes: as faculdades de Medicina originárias das Escolas Médico-Cirúrgicas, as Faculdades de Ciências da Escola Politécnica de Lisboa e da Academia Politécnica do Porto, assim como a Faculdade de Letras de Lisboa era originária (conforme se disse) do Curso Superior de Letras. Um curso de Engenharia ficou ligado à Faculdade de Ciências do Porto, mas o Instituto Superior Técnico (criado, como se constatou, no âmbito do Ministério da Fazenda) ficou à margem da Universidade, assim como os cursos de Educação Física, de Belas Artes e outros. E deve notar-se que nenhuma faculdade de Direito foi então criada, apenas tendo surgido em Lisboa em 1913, certamente, pelo menos em parte, por pressão política, pois foi seu primeiro director Afonso Costa. Nesse mesmo ano nasce finalmente o ministério da Instrução Pública (7 de Julho), cujo responsável foi o médico António Joaquim de Sousa Júnior.

Portanto, pode dizer-se que as duas faculdades de Letras, mas sobretudo a de Coimbra, perfizeram em 19 de Abril de 1911 os primeiros cem anos. Quanto à de Coimbra, a sua sede foi variando. As suas aulas foram-se distribuindo por várias instalações, entre elas o Colégio de S. Pedro. Mas logo que Manuel de Arriaga foi nomeado reitor, falou-se da sua instalação no edifício do inacabado Teatro Académico, pedido que foi sendo reiterado sucessivamente e aceite. Demoraram, no entanto, as obras de transformação e adaptação, pois em 27 de Abril de 1922, de acordo com um relatório sobre obras na Universidade enviado pelo reitor António Luís Gomes ao ministro do Comércio e Comunicações, ainda se não tinha dado a transferência das instalações para o edifício ${ }^{12}$,

\footnotetext{
${ }^{12}$ Cfr. J. Ferreira Gomes, ob. cit., pp. 392-393.
} 
que ficou conhecido na gíria académica, ironicamente, pela "Faculdade da peneira", porque nas insígnias da escola, que se encontravam no frontão principal, constava, para além das pirâmides e da famosa esfinge do Egipto, do Sol, do mocho, de livros e documentos, uma peneira, para peneirar o saber, a fim de apenas passar o melhor ou o mais importante, e o nome da escola, em latim, Liberalium Artium Facultas, a recordar afinal a origem remota da Faculdade de Letras, ou seja, a "Faculdade de Artes Liberais". No frontão das traseiras do edifício estava escrita a frase (hoje, infelizmente bem desactualizada pelo pragmatismo que grassa no mundo), provavelmente inspirada nos Provérbios do Velho Testamento, escrita em grego, "A Sabedoria é mais excelente do que o ouro", Sopfía aretotéra Khrysioy ${ }^{13}$.

Mas poderá dizer-se que a estrutura da Faculdade e os seus docentes se afastaram, apesar da laicidade da República, das "Letras sagradas"?

\section{A Faculdade de Teologia e a Faculdade de Letras de Coimbra}

A Faculdade de Teologia e a de Direito foram as faculdades mais atacadas quando se deu a implantação da República. Inclusivamente estudantes revolucionários, de tendência anarquista, que constituíram a chamada "Falange Demagógica", destruíram cátedras e borlas e capelos de lentes, para além de terem disparado contra os quadros dos reis D. Carlos e D. Manuel II da Sala dos Capelos ou sala Grande dos Actos. Foi um processo complexo que nem o reitor Manuel de Arriaga conseguiu inicialmente serenar e que provocou uma viva polémica na própria Assembleia Nacional Constituinte, em meados de 1911. Uma das ideias que aí pairou não foi o encerramento da Faculdade de Teologia, que pacificamente foi na prática extinta, mas sim o encerramento da Faculdade de Direito e a criação de uma Faculdade de Direito em Lisboa. Mas foi-se mais longe: atendendo às posições radicais de alguns estudantes anarquistas e ao radicalismo de um deputado, Miguel Abreu, foi proposta por este a extinção da Universidade de Coimbra, o que não foi admitido pelo parlamento. O que ficou no ar, para além do caso particular do estudante Aurélio Quintanilha,

13 "Procura adquirir a sabedoria, pois ela é melhor do que o ouro, e adquire a prudência, porque ela é mais preciosa do que a prata” (Provérbios. 16, 16). 
da Faculdade de Filosofia/Ciências, pertencente à "Falange Demagógica", que tinha agredido um seu professor, Álvaro Basto, é que a Faculdade de Direito era "reaccionária" e haveria que constituir outra em Lisboa. A questão envolveu outros lentes, como Guilherme Moreira, da Faculdade de Direito, acusado de estar contra as leis da República, tendo sido defendido por alguns deputados, e o reitor nomeado depois de Manuel Arriaga, Daniel de Matos, da Faculdade de Medicina.

Seja como for, nada se passou de grave nos inícios da República com a recém-criada Faculdade de Letras, mesmo tendo em conta que alguns dos lentes de Teologia se transferiram para a referida faculdade, razão porque mais tarde se passariam a apresentar com borla e capelo brancos (da Teologia) e azuis (de Letras). Assim, por decreto de 17 de Junho de 1911, os lentes de Teologia que passaram para Letras (outros, que chegaram a ser distribuídos por grupos, de acordo com o Anuário da Universidade, passaram à condição de aposentados), foram os seguintes: José Joaquim de Oliveira Guimarães, colocado no 1. ${ }^{\circ}$ grupo (Filologia Clássica), António Garcia Ribeiro de Vasconcelos e Joaquim Mendes dos Remédios no 2..$^{\circ}$ Grupo (Filologia Românica), Francisco Martins e Porfírio António da Silva no $4 .^{\circ}$ grupo (História) e Augusto Joaquim Alves dos Santos no 6. ${ }^{\circ}$ grupo (Filosofia). Deve dizer-se, porém, que, na prática, António de Vasconcelos mudou de grupo ou de secção de ensino, tornando-se um dos mais importantes professores de História e das então ditas "ciências auxiliares" (Paleografia e Diplomática, Numismática e Esfragística, Epigrafia) e escrevendo algumas obras de referência neste domínio. Alves dos Santos, para além de reger várias cadeiras de Filosofia, ficou conhecido especialmente pela sua investigação e ensino na área de Psicologia Experimental, integrada então em Filosofia, tendo sido, durante largos anos (1913-1924), director do seu Laboratório, e como professor da Escola Normal Superior. Entretanto, José Maria Rodrigues, por decreto de 8 de Junho de 1911, foi colocado na Faculdade de Letras de Lisboa, tendo sido, como se sabe, um ilustre camonianista.

Portanto, grande parte dos professores da Faculdade de Letras provieram da Faculdade de Teologia, razão por que a Faculdade, apesar da sua juventude, ocupa ainda hoje o primeiro lugar nas precedências das Faculdades, o que é visível nos cerimoniais. De resto, vejamos o nome de alguns professores que fizeram parte do corpo docente da Faculdade de Letras de Coimbra durante a República 
(não nos referimos aqui a alguns estrangeiros, que vieram leccionar a língua e a literatura dos seus países):

Eugénio de Castro e Almeida, mais conhecido, como escritor e professor, simplesmente por Eugénio de Castro, filho do professor da Faculdade de Filosofia e depois da Faculdade de Ciências Luís da Costa e Almeida: para além de ter sido professor de várias cadeiras no grupo e secção de Filologia Românica a partir de 1914, tornou-se, pois, conhecido como escritor, apreciado em vários países da Europa e da América, sendo um dos precursores do simbolismo, e veio a manifestar claras simpatias pelos regimes autoritários e, assim, pelo salazarismo.

Ferrand Pimentel de Almeida, do grupo e secção de Filologia Germânica depois de 1916, que havia estudado no Seminário de Évora e que se doutorara em Filosofia e Teologia em Roma pela Universidade Gregoriana: aderiu ao salazarismo, foi Presidente Câmara de Coimbra e procurador à Câmara Corporativa.

Joaquim de Carvalho, bacharel em Direito (1916) e doutor em Letras (1917), foi dos mais conhecidos professores da Faculdade na área de Filosofia, para além de ter sido administrador da Imprensa da Universidade desde 1922 até à sua extinção, em 1934, sem dúvida por ter sido um arreigado republicano demoliberal.

Manuel Gonçalves Cerejeira, do grupo e secção de História a partir de 1916, no qual se doutorou em 1918, fez o curso do seminário em Braga, vindo a ser em Coimbra um membro activo do CADC e do jornal Imparcial, em luta contra o laicismo republicano: foi um dos companheiros de Salazar e a sua sagração como cardeal patriarca de Lisboa abriu caminho à ligação da Igreja com o Estado Novo, apesar das suas polémicas conjunturais com o seu amigo Presidente do Conselho de Ministros.

João da Providência de Sousa e Costa, docente de Filologia Germânica a partir de 1916, doutorando-se em 1919, foi o fundador do Instituto Alemão e do seu Boletim, que veio a manifestar tendências germanófilas, e depois da revista Brasília (1942), por altura da vigência do Estado Novo de Getúlio Vargas.

Aristides de Amorim Girão, formado em Ciências Histórico-Geográficas e seu docente a partir de 1916, doutorando-se em 1922.

José Simões Neves, bacharel e doutor em Filologia Clássica, que foi membro desse grupo e secção de 1916 a 1920, tirou o curso de Teologia no Seminário de Coimbra. 
Manuel Serras Pereira, que foi bacharel em Direito e licenciado e doutor em Filosofia em 1923, apenas esteve na Faculdade como assistente de 1921 a 1925, na área de Psicologia.

Vergílio Correia (de nome completo Vergílio Correia Pinto da Fonseca), bacharel em Direito e só doutor em Letras em 1933, foi professor contratado de Estética e História da Arte, a partir de 1920, em Arqueologia em 1923-1924, em História Antiga em 1923-1930 e de outras cadeiras até à sua morte em 1944. Foi membro de várias academias estrangeiras, director do Museu Machado de Castro e conservador do Museu Nacional de Arte Antiga e do Museu Etnológico Português.

Carolina Wilhelme Michaëlis de Vasconcelos, alemã de nascimento, filha do professor Gustav Michaëlis e casada em Portugal, onde se estabeleceu desde 1876, com o arqueólogo e erudito Joaquim de Vasconcelos, era doutorada honoris causa por universidades alemãs e foi a primeira mulher professora da Universidade de Coimbra, na área de Filologia Românica, desde 1911, até á sua morte, em 1925.

Carlos Simões Ventura, formado e doutor em Filologia Clássica (1916 e 1917), foi seu docente a partir de 1916.

Como se vê, poucos professores eram propriamente republicanos assumidos, no sentido da militância demoliberal. Eram republicanos assumidos Alves dos Santos, que aderiu à República, tendo sido secretário de Teófilo Braga, pertencido ao Partido Evolucionista e, depois, ao Partido Liberal, presidente da Câmara de Coimbra, deputado e ministro do Trabalho no governo de Cunha Leal (16.12.1921 a 6.2.1922), e Joaquim de Carvalho, que sempre se manifestou como independente e procurou manter-se como professor, investigador e cidadão republicano. Muitos (mais de 50\%) estavam ligados a uma formação no âmbito das "Letras Sagradas" ou da Teologia e alguns tomavam posições como "católicos" e tradicionalistas, vindo a integrar-se outros no campo salazarista. E quando outro professor, Sílvio Lima, entrou para a Faculdade na área de Filosofia mas, especialmente, da Psicologia e da Teoria da História, em 1928 (doutorou-se em 1929), originou, como veremos, uma importante e significativa questão, do ponto de vista político, com a Igreja e com o Estado Novo.

O mesmo se pode dizer com alguns professores que, originários de outras faculdades, vieram dar o seu contributo à Faculdade de Letras. Não se pode dizer isso de Anselmo Ferraz de Carvalho, das Faculda- 
des de Filosofia / Ciências, que ensinou cadeiras de Geografia a partir de 1911, o qual manteve as suas ideias republicanas, tornando-se um destacado elemento da oposição ao Estado Novo. Nem mesmo de Joaquim Martins Teixeira de Carvalho, conhecido por "Quim Martins", professor de Anatomia na Faculdade de Medicina e administrador da Imprensa da Universidade de 1913 a 1921, que foi contratado para leccionar Estética e História da Arte de 1919 a 1921.

Alguns não serão anti-republicanos, mas também não se pode dizer que sejam fervorosos adeptos do regime, salientando-se outros pela sua ideologia católica ou pela proximidade de teorias políticas de direita ou mesmo pela sua ligação a Salazar ou ao salazarismo. António José Gonçalves Guimarães, lente de Mineralogia e Geologia das Faculdades de Filosofia / Ciências, e filólogo, professor de Filosofia no Seminário de Coimbra, manifestando um conhecimento enciclopédico, leccionou na Faculdade de Letras, na secção de Geografia, Desenho Aplicado à Cartografia (1912-1914) e, na secção de Filologia Clássica, Línguas e Literaturas Grega e Latina, de 1912 a 1919, pelo que lhe foi concedido também o doutoramento em Letras em 1917, ao abrigo da lei n. ${ }^{\circ} 616$. Paulo Merêa, da Faculdade de Direito e importante historiador do Direito, tornou-se professor provisório de História de Portugal em 1920-1923. Joaquim de Vasconcelos, erudito, que havia estudado num colégio em Hamburgo, foi, devido às suas qualidades de investigador e autodidacta, professor contratado de Arqueologia, apenas de 1915 a 1918. Não se divisam neles significativa militância política.

Mas o mesmo não sucedeu com outros. Eusébio Tamagnini de Matos Encarnação, professor da Faculdade de Ciências na área de Antropologia e professor contratado de Etnologia na Faculdade de Letras de 1912 a 1950, esteve ligado ao movimento nacional-sindicalista e foi ministro da Instrução Pública do governo de Salazar. Também - diga-se em parênteses - Luís Cabral Moncada, da Faculdade de Direito, aluno dos jesuítas do Colégio de S. Fiel, professor contratado de História de Portugal já na Ditadura Militar, 1928-1930, pertenceu igualmente ao nacional-sindicalismo, acabando por apoiar de forma clara, mas sempre fora do aparelho de Estado, o salazarismo. Por sua vez, João Serras e Silva, professor da Faculdade de Medicina, nas áreas de Higiene, de Patologia Interna e de Epidemiologia, foi professor contratado de Geografia Política e Económica (1919-1920), de História dos Descobrimentos e Colonização (1920-1933) e, mais tarde, de 
Higiene Escolar (1930-1933), depois de ter leccionado cadeiras na Escola Normal Superior (extinta em 1930) e no Seminário de Coimbra: pertenceu a um grupo de católicos interessados pela Sociologia ${ }^{14} \mathrm{e}$ a sua casa abria-se ao grupo de professores militantes ligados ao CADC, entre os quais estavam Salazar e Cerejeira.

A Faculdade de Letras seria, pois, uma continuação da Faculdade de Teologia ou dos estudos de "Letras Sagradas"? Era esta afinal a tese do ministro da Instrução Pública Leonardo Coimbra, ao justificar a sua extinção e a formação de uma nova Faculdade no Porto em 1919.

\section{A tentativa da extinção da Faculdade de Letras em Coimbra e a formação efémera da Faculdade de Letras no Porto}

Independentemente do juízo que, na época, se tivesse da Faculdade de Letras, pró ou contra, o certo é que dela saiu, em parte, sobretudo da acção do Padre Manuel Gonçalves Cerejeira, o espírito que animou o sector católico, que lutou nas suas organizações, nomeadamente no CADC e, depois, no Centro Católico Português, de que Salazar chegou a ser deputado à Assembleia Legislativa, nas ruas e em jornais e revistas (como o Imparcial e a revista Estudos) a favor da Igreja, o que se verificou paralelamente e em consonância com um movimento que fez renascer as praxes, as festas e os rituais académicos tradicionais. Deve recordar-se, de resto, que o primeiro reitor eleito da Universidade, Mendes dos Remédios, saiu da Faculdade de Letras e havia sido lente de Teologia: pertencerá depois, com Salazar e Manuel Rodrigues Júnior, ao trio de Coimbra do efémero governo de Mendes Cabeçadas, saído da revolução de 28 de Maio de 1926; e que o primeiro director

${ }^{14}$ Escrevera textos de tipo sociológico no domínio da Medicina, mas publicou também vários artigos na revista da Faculdade de Letras, Biblos, subordinados ao tema A Ciência Social na Educação e na História, que teve uma edição separada. $\mathrm{O}$ interesse pela Sociologia levou a Portugal o sociólogo Léon Poinsard que percorreu o país, tendo publicado em 1912 o livro, traduzido para português, Le Portugal inconnu: Portugal ignorado. Estado social, economico e politico. Seguido de um appendice relativo aos ultimos acontecimentos, Porto, Magalhães \& Moniz Ld ${ }^{\mathrm{a}}$. Editores, 1912. Mais tarde outro sociólogo, Paul Descamps, fez conferências em Portugal e veio mais tarde a publicar algumas obras, uma delas postumamente. 
da Faculdade de Letras, António Vasconcelos, era também proveniente de Teologia e sacerdote católico. Por isso, não nos custa a entender a argumentação de Leonardo Coimbra, em 1919, durante o seu breve ministério da Instrução Pública (30.3.1919 a 29.6.1919), no governo do democrático Domingos Leite Pereira.

Quem era Leonardo Coimbra ${ }^{15}$ ? Ligado ao movimento da Renascença Portuguesa, Leonardo Coimbra evoluiu desde o anarquismo ao republicanismo democrático e à dissidente Esquerda Democrática. No sentido académico, depois de frequentar a Escola Naval, tentou seguir o magistério, começando por frequentar a Academia Politécnica do Porto. É então que trava conhecimento com Jaime Cortesão, Augusto Casimiro e Teixeira de Pascoaes. Transfere-se, de seguida, para o Curso Superior de Letras de Lisboa, a fim obter aprovação em cadeiras preparatórias para a função docente e inicia, finalmente, a sua actividade de professor do ensino liceal no Porto. Concorre, entretanto, sem sucesso, a um lugar de professor assistente de Filosofia na Faculdade de Letras de Lisboa, acabando, assim, por seguir a carreira docente no ensino liceal e na Faculdade de Letras do Porto, que fundou como ministro e de que foi director

No breve espaço de tempo do seu aludido ministério, fez sair dois decretos que originaram grande discussão, sobretudo o segundo. Em 2 de Maio de 1919 foi publicado o decreto com força de lei n. ${ }^{\circ} 5.491$ que alterava a composição curricular dos cursos de Filosofia nas faculdades existentes de Lisboa e de Coimbra, passando a ter as seguintes cadeiras (artigo 1. ${ }^{\circ}$ ): Matemáticas Gerais, Física Geral, Química Geral, Biologia, Sociologia, Psicologia, Curso Prático de Psicologia, Teoria da Experiência (ciência, arte, moral), Metafísica, três cadeiras de História da Filosofia - Antiga, Medieval e Moderna e Contemporânea - e Curso Prático de História da Filosofia. Desta forma, pretendia-se "modernizar" o ensino da Filosofia, afastando o espírito "escolástico" que, segundo Leonardo Coimbra, caracterizaria o ensino praticado, sobretudo em Coimbra.

\footnotetext{
${ }^{15}$ Ver sobretudo Manuel Ferreira Patrício, A pedagogia de Leonardo Coimbra. Teoria e prática, Porto, Porto Editora, 1992. A tese data de 1983. Na edição que citamos pode ver-se uma vasta bibliografia de Leonardo Coimbra, sobre Leonardo Coimbra e sobre questões de Pedagogia e de história da Pedagogia.
} 
Afinal preparava-se com este decreto o que viria a aparecer no diário oficial dias depois, em 10 de Maio de 1919 (decreto n..$^{\circ}$ 5.770). Nessa lei, considerava-se, no preâmbulo, que o meio e o professorado de Coimbra viviam "como que insulados no seu trabalho especulativo, literário e científico" e que a Faculdade de Letras preparava os seus alunos de modo a dar preferência à "erudição livresca", mais do que às "especulações originais do espírito moderno", o que se comprovava "na filosofia revelada nas obras dos seus principais professores e alunos laureados", a qual traduzia "uma quase completa orientação tomista de forma escolástica". Por outro lado, como considerava "as condições sociais do Porto de mais larga actividade que as de Coimbra", justificava a criação ali, como se via no artigo $1 .^{\circ}$, de uma Faculdade de Letras, desanexando-a da Universidade de Coimbra (no dizer do diploma: "criada em substituição da extinta Faculdade de Teologia"). Sintomaticamente, pelo mesmo decreto, era instituída em Coimbra - para contrabalançar o seu alegado espírito "escolástico" uma Faculdade Técnica, que teria anexa "uma Escola de Belas Artes".

Esta reforma não foi avante no que respeita à extinção de facto da Faculdade de Letras de Coimbra, embora tivesse sido criada no Porto uma faculdade. A crítica choveu de todos os lados, mesmo de professores considerados avançados para o seu tempo no âmbito da faculdade de Coimbra. Alves dos Santos, que foi (como se disse) director do Laboratório de Psicologia, como deputado por Coimbra do Partido Evolucionista, não protestou contra a lei de alteração curricular do curso de Filosofia mas sim contra o decreto que extinguia em Coimbra a Faculdade de Letras. Foi, porém, Joaquim de Carvalho quem mais e melhor protestou, de forma escrita e com uma argumentação mais sólida, embora centrada sobretudo na sua pequena experiência pessoal de investigador e assistente. O seu opúsculo $A$ minha resposta é um claro e corajoso manifesto contra a política de Leonardo Coimbra ${ }^{16}$. De uma forma directa, ergueu-se também contra o reitor nomeado,

${ }^{16}$ A minha resposta ao último considerando do decreto que desanexou a Faculdade de Letras da Universidade de Coimbra, Coimbra, Tipografia França Amado, 1919. Pode ler-se a sua transcrição na Obra Completa de Joaquim de Carvalho, editada pela Fundação Calouste Gulbenkian: vol. VII: Escritos sobre a Universidade de Coimbra (1919-1942), Lisboa, Fundação Calouste Gulbenkian, 1992, pp. 1-11. 
Joaquim Coelho de Carvalho, assumiu-se como discípulo de Kant e de Hegel, afirmou a liberdade que existia em Coimbra, onde todos os que estavam habilitados fizeram "actos grandes na Universidade, quaisquer que fossem as ideias políticas e religiosas". E sublinhou, como ponto de princípio, o seguinte, recordando, certamente, as práticas inquisitoriais, que tão bem conhecia como historiador, e parecendo prever o que se iria passar em tempos de autoritarismo político institucionalizado:

Se há uma estrutura mental que a República deva destruir é a da purificação. Para purificar o espírito, queimavam-se corpos; impediam-se leituras; fiscalizava-se o pensamento. O resultado viu-se e, tão baixo, vê-se ainda. Na ordem social, o estagnamento; na ordem individual, o ódio tão arreigado da nossa constituição psicológica, que constitui - e é tão doloroso reconhecê-lo - uma verdadeira categoria, sob a qual se ordenam e concebem as relações sociais.

Reincidir nesse erro é justificar o passado e agravar o futuro. Que a imperial Alemanha o fizesse, compreendia-se. Mas que um governo da República vá ao assalto dos próprios fundamentos da Democracia, com a turba-multa das paixões, é um crime e uma ignomínia!

Não o fará, porque creio ainda nos seus destinos, com a mesma fé dos tempos de estudante. Mas se o fizer, não o fará sem o meu protesto e sem a minha indignação. ${ }^{17}$

E, ironizando com os termos utilizados na lei de extinção da Faculdade de Letras de Coimbra, praticamente termina o seu texto desta forma, não sem antes ter transcrito um extracto do referido decreto n. ${ }^{\circ} 5.770$ :

Pensam assim os tomistas de forma escolástica da Faculdade de Letras da Universidade de Coimbra. ${ }^{18}$

Para finalizar esta descrição - que pretendeu comprovar o sentido das reformas levadas a efeito por Leonardo Coimbra, o qual (conforme se disse) continuou a sua acção como docente na Faculdade de Letras do Porto, onde fez alguns discípulos dilectos -, digamos que a reacção às suas medidas levou à demissão do referido reitor interino, da confiança

\footnotetext{
${ }^{17}$ Na edição da Fundação Gulbenkian, acima referida, p. 10.

${ }^{18}$ Idem, p. 10.
} 
política do governo para levar a efeito as reformas em Coimbra, o referido Joaquim José Coelho de Carvalho, demissão que ele próprio solicitou em 26 de Junho de 1919, saindo o ministro poucos dias depois, no dia 29 do mesmo mês. Coelho de Carvalho é, por isso, dos raros reitores que não tem o seu quadro na galeria reitoral distribuída por diversas salas e corredores na Universidade de Coimbra, mas Manuel Rodrigues não deixou, correctamente, de inserir o seu retrato no livro que dedicou ao reitores ${ }^{19}$. Quanto ao futuro político de Leonardo Coimbra, voltará ao governo no fim de 1922 até ao início de 1923, apenas por um período ligeiramente superior a um mês.

Esta argumentação de Joaquim de Carvalho não obsta que tivesse consciência de que a Universidade (não só a de Coimbra, mas também a de Lisboa) estaria arreigada a um significativo espírito tradicional e possuiria uma organização burocrática que tirava o tempo a estudantes e professores para pensarem nos problemas científicos e culturais do seu tempo, que veio a denunciar, de forma pública ou particular, em escritos posteriores, já da época salazarista, sobretudo no artigo "Reflexão outonal sobre a universidade de todo o ano" (Diário Liberal, de Lisboa, 8 de Novembro de 1933) ${ }^{20}$.

De forma mais directa e precoce, o fez um jovem professor a que já aludimos, o qual entrou no magistério em 1928, Sílvio Mendes de Lima, numa polémica de grande significado simbólico, que vamos focar depois de falarmos do regresso dos rituais escolares pela mão de professores da Faculdade de Letras.

\section{Os rituais académicos, o valor dos símbolos e o "regresso do sagrado"}

Como se disse, o republicanismo extinguiu na prática (embora não legalmente) todos os rituais que acompanhavam os actos académicos, numa demonstração de alegado antitradicionalismo, não pensando,

${ }^{19}$ Ver A Universidade de Coimbra e os seus reitores. Para uma história da instituição, Coimbra, Arquivo da Universidade, 1990, p. 511.

${ }^{20}$ Ver a sua transcrição em António Costa Lobo Vilela (Selecção, fixação de textos e notas), Luís Reis Torgal (Estudo introdutório) e Eduardo Marçal Grilo (Prefácio), Lobo Vilela, a polémica sobre a Universidade e o ensino nos inícios do Estado Novo, Lisboa, Fundação Calouste Gulbenkian, 2009, pp. 161-164. 
obviamente, nesses primeiros tempos, no valor da Tradição como fenómeno de cultura. Assim, terminaram episodicamente os doutoramentos solenes na Sala dos Capelos, assim como quase se extinguiram as praxes e as festas nos meios estudantis. Se estas começaram a pouco e pouco a reafirmar-se no espaço coimbrão, passando mesmo a Lisboa e ao Porto, onde a capa e batina seria ainda de uso comum, também ressurgiram os rituais universitários. Como já o provámos noutro estudo, ${ }^{21}$ apareceram por "via sacerdotal" na Faculdade de Letras.

Na verdade, apesar de, a partir de 1914, mas sobretudo depois de 1917 , se tornar cada vez mais corrente o que chamamos "doutoramentos científicos", isto é, o doutoramento resultante da prestação de provas diversas e complexas, previstas primeiro na legislação de Janeiro de 1911 e posteriormente regulamentadas através de outras leis gerais e particulares, que originava doutores ipso facto todos os que tivessem realizado essas provas, o certo é que isso não invalidou que, em cerimónias universitárias mais ou menos privadas, não se concedesse a borla e o capelo ao novo doutor.

Não sabemos quando é que essa cerimónia se iniciou, mas conhecemos um caso, por assim dizer, paradigmático. Trata-se da imposição das "insígnias doutorais", na Sala do Senado, em 30 de Janeiro de 1918 (em pleno sidonismo), ao "novo Doutor em Letras (secção de Ciências históricas e geográficas) Senhor Manuel Gonçalves Cerejeira". E temos disso conhecimento graças à publicação do discurso que então foi proferido pelo Doutor António de Vasconcelos, seu colega na faculdade e no sacerdócio.22

Nesse discurso, António de Vasconcelos começa por recordar os tempos, "não há muito passados", "em que na Universidade se graduava um novo Doutor": "era dia solene e de grande festa, não só para a nossa veneranda Alma Mater, mas também para toda Coimbra". E descreve todo essa festa em honra do "jovem triunfador", "triunfador nas pugnas incruentas, mas não menos gloriosas, das Letras e das Ciências". "Nessas solenidades académicas - continuava o orador - ressuscitava-se

21 "Quid petis? Os «doutoramentos» na Universidade de Coimbra”, in Revista de História das Ideias, n. ${ }^{\circ}$ 15, Coimbra, 1993.

${ }^{22}$ Cfr. D. Manuel Gonçalves Cerejeira, Vinte anos de Coimbra, Lisboa, Edições Gama, 1943, pp. XXI-XXVII. 
o passado, animava-se o presente, preparava-se o futuro. Elas eram uma recordação das antigas glórias, um prémio ao talento e virtude, um estímulo ao progresso". Como se vê, a simbologia usada por António de Vasconcelos é a simbologia do cavaleiro medieval, do cavaleiro das letras e das ciências, como havia outro cavaleiro, que era o cavaleiro das armas. Era afinal a velha ideia de "honra" e de glória, do triunfo, tão próprio do "Antigo Regime", que por vezes punha em confronto o valor relativo das letras e das armas. De resto - completemos nós em Salamanca havia o costume de escrever nas pedras castanhas dos edifícios da cidade os Victores, ou seja, o nome e os símbolos daqueles que triunfavam e chegavam ao doutoramento, com tinta vermelha feita com sangue de touro e almagre.

Comparando o "passado" e o "presente", Vasconcelos recorda que restava apenas "uma saudosa lembrança", pois tudo havia sido suprimido. E explicava, abrindo, com essa saudade, as portas à ideia de renovação do passado:

$\mathrm{Na}$ antiga e gloriosa Universidade de Coimbra estão de facto suprimidas todas as solenidades. Por determinação da lei? Não! A legislação universitária apenas determina que a colação do grau de Doutor resulte ipso facto da aprovação em todas as provas do respectivo exame; suprimiu portanto a cerimónia dessa colação, mas nem aboliu as insígnias doutorais consagradas pelas antigas leis e costumes, nem proibiu que o novo Doutor fosse investido com solenidade, segundo a tradição tantas vezes secular, na posse dessas insígnias.

Entretanto nós temos de aceitar os factos, como eles são; havemos de nos conformar com a realidade das cousas: e a realidade é que todo esse cerimonial desapareceu..$^{23}$

E, na verdade, António de Vasconcelos, sacerdote, doutor em Teologia, conhecedor da liturgia do sagrado, podia explicar como ninguém ao seu colega, igualmente clérigo, o valor dos símbolos, no contexto de um conceito corporativo de Universidade. E assim o fez:

Senhor Doutor Manuel Gonçalves Cerejeira:

As vestes e insígnias, que neste momento o exornam, são altamente honrosas pelas tradições que representam e pelo simbolismo que as dignifica.

${ }^{23}$ Vinte anos de Coimbra, Lisboa, Edições Gama, 1943, p. XXV. 
Reconhecemos na toga e capa de cor preta o traje grave, comum, igualitário, que, modificado através dos séculos, acompanha desde a sua infância as Universitates Magistrorum et Scholarium, e que encontramos figurado em esculturas e iluminuras medievais. Sobre elas assenta o capelo, essa veste brilhante e muito ostentosa, na qual vemos simbolizada a glória, a dignidade, a honra, de que a alta cultura científica reveste os que realmente a possuem.

No anel temos o símbolo e penhor da aliança e afecto que devem unir os graduados entre si, como irmãos, e para sempre; e da fidelidade, dedicação e respeito, que são obrigados a tributar à grande Mãe espiritual, à benemérita Universidade que os educou, e lhes conferiu a suprema honra académica.

Finalmente o barrete doutoral representa a coroa do triunfo, alcançado nos jogos literários, nas pugnas científicas: a antiga capela de ramos entrelaçados de bácaro e de louro. ${ }^{24}$

O Padre Doutor António de Vasconcelos esteve com certeza - como já o insinuámos - na base do processo de revitalização da cerimónia de "imposição de insígnias" ou do "capelo", e do seu ritual. Mas, talvez ainda mais significativamente do que ele, falou o Padre Doutor Manuel Cerejeira do "valor dos símbolos", para empregar as palavra que ele terá utilizado - ou os seus editores, à frente dos quais estava o bispo de Helenópole, D. Manuel Trindade Salgueiro ${ }^{25}$ - para intitular o discurso proferido durante a primeira dessas cerimónias realizada na "sala dos capelos": o "acto de se conferirem as insígnias doutorais ao novo Doutor em Letras (secção de Ciências geográficas) Senhor Aristides de Amorim Girão", em 28 de Maio de $1922^{26}$.

${ }^{24}$ Ob.cit., pp. XXVI-XXVII.

${ }^{25} \mathrm{O}$ livro que temos vindo a citar foi prefaciado pelo bispo de Helenópole, D. Manuel Trindade Salgueiro, um dos bispos mais próximos do Estado Novo, que veio a ser professor da Faculdade de Letras.

${ }^{26}$ Não é, no entanto, o primeiro "doutoramento solene" que, na República, se realiza na sala dos capelos, embora seja o primeiro de um professor da Universidade de Coimbra. Em 15 de Abril de 1921, efectuou-se o doutoramento honoris causa dos comandantes das forças aliadas vencedoras da Primeira Guerra Mundial, o Marechal Joffre, de França, o Generalíssimo Diaz, de Itália, e o General Smith Dorrien, de Inglaterra, que haviam visitado Portugal. 
Gonçalves Cerejeira, elogiando Amorim Girão, começou por se referir ao sentido desta cerimónia que tinha sido interrompida havia "tantos anos!" e que correspondia à "consagração a uma espécie de nobreza que se não confere por...decreto - o talento". No velho estilo de considerações da Universidade de "Antigo Regime" - e as palavras são elucidativas - refere-se ainda à "Ordem dos Doutores de Capelo", que em Coimbra se havia erigida por lei e por tradição e que agora se voltava a reunir. E é então que disserta, longamente, sobre "o valor dos símbolos", numa reflexão interessantíssima que nos revela a sua concepção do valor simbólico das cerimónias. Por isso vamos transcrever a parte que consideramos mais significativa do seu discurso:

Parecerá talvez a alguns que é um símbolo morto que se ressuscita. Ora, além de que o que ressuscita é porque não está morto, os símbolos podem transformar-se, mas não morrem... senão com a morte da civilização, pois como ela nascem e perduram.

O símbolo é, como o definiu um poeta, "aquela verdade que tem face de mentira". Ele exprime, numa linguagem de beleza, que encanta os sentidos, realidades profundas, que estão além do que a língua humana pode manifestar... Felizmente para... o maior número, o homem não se define como uma inteligência pura: o símbolo, sendo uma linguagem de imagens, é mais expressivo que a própria palavra. E esta mesma que é senão o símbolo imperfeito do pensamento? Assim como sem a palavra não há pensamento, também sem os símbolos não há civilização - eles traduzem o que há nela de mais íntimo: a alma.

[...]

Toda a liturgia é a admirável expressão simbólica de um culto em espírito. Todos os nossos sentimentos têm a sua - e os que julgam que não praticam culto algum, têm pelo menos o mau gosto de praticarem o culto de... si próprios. Porque dotado de sensibilidade, o homem traduz por atitudes, imagens e símbolos, a vida da sua alma. Quem ignora que todo o coração, quando ama, logo se acomoda a um velho rito, que os outros também já realizaram mas que cada um julga único, porque, como o cardeal dizia da Primerose, todos pensam ter descoberto...o amor? Parece que a palavra foi dada aos homens para se... não compreenderem, tão raro eles concordam; mas a linguagem dos símbolos, falam-na e compreendem-na mesmo os homens que falam línguas diferentes. 
A cerimónia de hoje é a ostentosa liturgia por meio da qual a velha Universidade rende o seu culto ao que é a sua própria razão de ser: a realeza do espírito. Neste templo de Minerva, convém que se não deixe apagar o fogo sagrado no altar. Se ele se apaga, se os sacerdotes já não têm fé, se o culto se não pratica, - depressa o templo universitário ficará deserto. Como queremos nós manter o prestígio da nossa Universidade, se atentamos contra aquilo que a faz viver ainda contra tudo: - o prestígio plurissecular da sua tradição? Ou confiaremos tanto na glória própria, que pensemos, ela pode dispensar a de todos que se sentaram neste mesmo lugar? O que hoje solenemente realizamos é o símbolo da nossa comunhão com todos que antes de nós a tornaram célebre - no culto da Ciência. ${ }^{27}$

Trata-se, na realidade, de um texto fundamental para entender o sentido com que foi reabilitada a "cerimónia do capelo". Estamos perante uma concepção quase totalizadora do sentido dos símbolos, como é próprio das mentalidades fideístas. Cerejeira crê na eficácia dos símbolos não tanto como representações, mas como realidades sem as quais não há realidade. O seu objectivo é sacralizador e daí todo o inevitável processo de mitificação de Coimbra pelos mestres da Universidade do Estado Novo que ocupavam a cátedra ou se preparavam para nela se sentar nesta década de 20 e mesmo antes. A iconoclastia republicana - que de facto existiu - tinha o sentido de dessacralização da Universidade e de a entender sobretudo como um espaço da Razão. Daí que não pudesse ser entendida por homens como Cerejeira, que, na linha bergsoniana, atacavam sistematicamente o racionalismo, e que, por outro lado, pretendiam dar à ciência uma dimensão onde a Fé tinha a sua presença fundamental. Daí a polémica que se verificará alguns anos depois entre Cerejeira e Sílvio de Lima - ela tem um significado especial, pois representa o debate entre a ideia de Ciência penetrada pela Fé e essencialmente nela assente e a ideia de Ciência que põe a Fé entre parênteses e se apoia fundamentalmente na Razão.

$\mathrm{O}$ que Cerejeira defendia era um culto na Universidade e à Universidade. Não um culto cívico, à maneira republicana, mas um culto onde o religioso se instila na própria instituição e lhe confere um sentido de "sacramento". Na verdade, o culto da concessão de insígnias doutorais não valia como um simples acto de conferir símbolos,

${ }^{27}$ Ob. cit., pp. 174-176. 
representativos sem dúvida, mas simples símbolos - como por certo pensaria o Reitor, o republicano António Luís Gomes, ao restaurar o cerimonial - que vinham apenas completar o acto mais importante, que era o "doutoramento científico", o único afinal existente como "real", que conferia ipso facto o grau de doutor. O culto, como qualquer forma de culto católico, valia como um"sacramento", sem o qual não há doutoramento verdadeiro, tal como não havia casamento só com o casamento civil e sem o casamento religioso, único acto abençoado por Deus. Neste caso não é propriamente Deus que está presente, mas é a Universidade, como instância sacralizadora que abençoa, através da figura "sacerdotal" do reitor, e que, ao exercer o seu munus, se dignifica, se honra, se sacraliza.

Assim terminava o Padre Doutor Gonçalves Cerejeira a sua oração:

Há cultos que honram não só a quem os recebe - mas também a quem os presta. Celebrar o talento e o saber, é, no fim de contas, um acto de fé no valor do espírito - razão de ser da Universidade.

Postergar o nosso culto doutoral é atentar contra a nossa própria razão de existir.

A Universidade de Coimbra, restaurando as suas velhas e venerandas galas para revestir o Doutor Aristides de Amorim Girão nas insígnias doutorais, honra-o com a mais alta distinção académica. Mas, honrando-o, honra-se a si própria, pois honra nele aquilo pelo que ela vive. ${ }^{28}$

O acto que se realizou nas cerimónias de "imposição de insígnias" de Amorim Girão confirma também as reflexões que fizemos acerca do discurso de Cerejeira. Na verdade, pela primeira vez, existia uma cerimónia de colação a um membro já doutorado. Mas é como se essa cerimónia tivesse um valor total - como acontecia realmente antes de 1911 - pois o cerimonial que, como já aludimos, deveria ter sido estudado pelo Padre Doutor António de Vasconcelos (a quem Amorim Girão dirigiu uma palavra de louvor, apesar da sua ausência por motivo de doença), mantinha em muitos aspectos as fórmulas do antigo ritual. Continuou a ser perguntado ao "novo doutor" (e agora não simplesmente candidato a doutor, como era no tempo da Monarquia), através do reitor-cancelário: Quid petis? Ao manter o formulário, numa

\footnotetext{
${ }^{28}$ Idem, pp. 184-185.
} 
versão, por assim dizer, "sacramental" do acto, estava afinal a criar-se, ao contrário do que se dizia, uma nova tradição, a tradição que ainda hoje se usa, embora cada vez mais despojada do seu sentido "sagrado" e do seu carácter de "investidura", que ainda assim justificava, de alguma maneira, esse sentido "sacramental" e o seu formulário.

Mas também terá havido inovações na cerimónia, adequadas às circunstâncias inéditas deste "novo" tipo de "doutoramento solene". A cor da borla e do capelo, azul escuro, como dos mestres da extinta Faculdade de Artes e, nos casos dos doutores originários de Teologia (como sucedia agora com vários professores), o branco sobre o azul, como de resto já prescreviam os "estatutos velhos" de 1653 (confirmação por D. João IV dos estatutos filipinos de 1597, reformados em 1612), para o caso dos doutorados que eram também mestres em Artes ${ }^{29 .}$

Portanto, pode dizer-se que foi a Faculdade de Letras - a qual, em certo sentido, herdou a tradição da Faculdade de Teologia, assim como herdou alguns dos seus lentes - que reergueu os rituais dos doutoramentos, extintos, ao menos na prática, pelo laicismo republicano.

\section{O significado de um debate: Sílvio Lima versus Manuel Gonçalves Cerejeira}

O Padre Manuel Gonçalves Cerejeira foi, de facto, com o Padre António de Vasconcelos, uma personalidade de grande significado no contexto da Faculdade Letras e da vida do país, a iniciar um processo de alteração política no sentido de um Estado autoritário. Apesar da continuação da fórmula da separação do Estado "em relação à Igreja Católica e a qualquer outra religião" (artigo 46. da Constituição de 1933) - o que o próprio Cerejeira, já Cardeal, contestou, em carta dirigida a Salazar -, o Estado Novo acabou por dar grande importância ao credo católico, como veículo de educação e ao serviço da ordem. Recorde-se que Salazar fora, acima de tudo, como estudante e professor, um militante católico, ainda que, como estadista, se tivesse envolvido

${ }^{29}$ Cfr. Estatutos da Universidade de Coimbra (1653). Edição fac-similada. Coimbra, Por ordem da Universidade, 1987, lib. III, tit. XXIV, Das insignias dos Doutores, e Bachareis formados nos actos publicos, pp. 179-181. 
em reflexões de tipo "fascista", devido ao significado que tinha então o regime italiano e à pressão de alguns sectores mais próximos da influência de Mussolini, como foi o caso de António Ferro.

Nesta perspectiva, é muito importante o debate entre o republicano liberal Sílvio Lima e o Padre Cerejeira, assim como o éa sua consequência política. Tudo se passou, todavia, já no tempo da Ditadura Militar e do início do Estado Novo, se bem que a obra que lhe deu origem, de Manuel Gonçalves Cerejeira, é de 1924, a que se seguiram logo edições em 1928 e 1930 (e depois várias outras) ${ }^{30}$. Limitemo-nos a recordar que foi o livro de Sílvio Lima, Notas críticas ao livro do sr. Cardeal Cerejeira "A Igreja e o pensamento contemporâneo" ${ }_{31}$ que originou essa grande polémica entre o pensamento laico e pensamento religioso. Em síntese, enquanto Cerejeira procurava entender a história com a presença do divino, formulando um juízo historicista que apontava para uma meta, o "Renascimento Cristão", Sílvio Lima negava a cientificidade dessa tese, opondo, pois, esse tipo de livro de filosofia da História ao rigor da tese de doutoramento de Cerejeira sobre o humanista Clenardo ${ }^{32}$.

Esta teoria "heterodoxa" de Sílvio Lima, a juntar à sua dissertação sobre $O$ Amor Místico ${ }^{33}$, com que desejava apresentar-se a provas para professor extraordinário no ano de 1935, foram, pois, suficientes para precipitar o seu processo de exoneração, que se verificou logo a seguir ao decreto $\mathrm{n}^{\circ} .25317$, de 13 de Maio desse ano, que obrigava os funcionários públicos a integrarem-se nos princípios fundamentais do Estado Novo. Se Joaquim de Carvalho não foi atingido nesse processo de exoneração, viu a Imprensa da Universidade, de que era administrador, ser extinta um ano antes, em 1934. O Amor Místico terá sido a última obra ali publicada, mas que apenas foi vendida clandestinamente.

Estas motivações que, na prática e de forma menos ideologicamente comprometida do que de maneira insinuadora, levaram ao renascer do espírito das "Letras Sagradas" na Faculdade de Letras, ou em certos meios docentes, levou tanto Sílvio Lima como Joaquim de Carvalho

\footnotetext{
${ }^{30}$ A Igreja e o pensamento contemporâneo, Coimbra, Coimbra Editora, 1924.

${ }^{31}$ Notas críticas ao livro do sr. Cardeal Cerejeira "A Igreja e o pensamento contemporâneo”, Coimbra, Livraria Cunha, 1930. Segunda edição corrigida e ampliada em 1931.

${ }^{32}$ O Renascimento em Portugal-Clenardo, Coimbra, 1917-1918.

${ }^{33} \mathrm{O}$ Amor Místico. Noção e valor de uma experiência religiosa, vol. I, Coimbra, Imprensa da Universidade, 1935.
} 
- como o fizeram os intelectuais da "Renovação Democrática", alguns deles discípulos de Leonardo Coimbra - a criticarem a Universidade e sobretudo até o espírito da Faculdade de Letras. Joaquim de Carvalho deixou um apontamento recolhido pelo seu filho, Joaquim Montezuma de Carvalho, dos anos cinquenta, mas que seria válido, com certeza, com maioria de razão, para anos antes:

Ambiente da Faculdade por 1950 e seguintes. O ambiente tornou-se clerical. Não era só o número de padres e freiras, com seus hábitos; era sobretudo a transformação da mentalidade. O silêncio nos corredores, a compostura obediente, as reverências aos professores, a sensação da existência de uma fiscalização sempre presente, o anonimato espiritual, a indiferença por tudo o que cá fora se discute e apaixona. Seminário e convento. Neste ambiente a formação da mocidade não podia deixar de gerar seres mutilados e insignificantes ${ }^{34}$

Nos anos sessenta, Sílvio Lima viu ser censurado um artigo que era uma resposta a um inquérito sobre a Universidade lançado pelo jornal A Capital, intitulado "História, magistra vitae". Esse artigo constituía uma crítica à Universidade portuguesa. Nele referia-se à "infiltração do vírus político (no sentido pejorativo da palavra)" na Universidade, o que a levou a perder a autonomia, nos seus diversos sentidos: "nomeação das suas autoridades administrativas (reitores, vice-reitores, directores das Faculdades) assente em critérios de predominante, senão exclusiva ortodoxia política"; "nomeação do pessoal docente, recrutado (como é da lei) mediante rigorosas provas públicas, mas só efectivada sob selecção política ministerial e com a prévia aprovação secreta da autoridade policíaca, zelosa da integridade e defesa do Estado e da salus populi"; expulsão de universitários "por meras razões de pretendida subversão política, sem prévio processo jurídico de objectivo julgamento"; "anulação da viva personalidade crítica do professor"; "repúdio de obras científicas", "rotuladas estas não raro por personalidades incompetentes nos respectivos assuntos como unidades a sepultar no Index Librorum Prohibitorum Universitatis de raiz político-censória”, etc. Com coragem procurou, publicamente, em momento de pretensa abertura política e cultural, poucos meses depois da subida ao poder de

\footnotetext{
${ }^{34}$ In Mar Alto, Figueira da Foz, n. ${ }^{\text {ss }} 403$ a 406, de 8 a 29 de Maio de 1974.
} 
Marcello Caetano, tomar uma posição dura contra o que se passava na Universidade, pensando certamente na Faculdade que melhor conhecia, a Faculdade de Letras ${ }^{35}$.

\section{A Faculdade de Letras e as mulheres}

A República originou, como se sabe, o reforço do movimento feminista e sufragista, com a ideia do sufrágio universal. Mas, na prática, nunca as mulheres conseguiram adquirir direito de voto, ainda que se tivesse verificado o voto da médica Carolina Beatriz Ângelo nas eleições de 1911 para a Assembleia Nacional Constituinte, que afinal limitou-se a aproveitar uma lacuna da lei, que logo a seguir foi corrigida, referindo-se exactamente o sexo do universo eleitoral. Ou seja, pode dizer-se que a formação universitária, na verdade crescente, que se deu no âmbito das mulheres a partir do final do século XIX, e sobretudo durante a Primeira República, não trouxe nenhum efeito em termos de sufrágio político, tendo sido aproveitada, por outro lado, pelo Estado Novo, altura em que, numa lógica corporativa e selectiva, se permitiu que certas mulheres votassem e fossem eleitas para a Assembleia Nacional.

Conforme se vê no primeiro e único estudo que conhecemos sobre o tema, de Joaquim Ferreira Gomes ${ }^{36}$, a primeira mulher a frequentar a Universidade de Coimbra não era de Letras. Tratou-se de Domitila Hormizinda Miranda de Carvalho, natural de S. Martinho de Travanca, concelho de Vila da Feira, do distrito de Aveiro, filha de um professor primário. Em 1891-1892 inscreveu-se no $1 .^{\circ}$ ano de Matemática. Depois foi frequentando cadeiras de Matemática e Filosofia.Até 1896 foi a única mulher a frequentar a Universidade de Coimbra. Em 1889-1890, depois de completar os preparatórios que lhe davam acesso à Faculdade

${ }^{35}$ Ver o nosso artigo "«Um homem humilde, mas livre na sua investigação». Sílvio Lima e a sua correspondência no processo da PIDE/DGS”, in Estudos em homenagem a João Francisco Marques, Porto, Faculdade de Letras do Porto, 2001, vol. II, pp. 473-498.

${ }^{36}$ A mulher na Universidade de Coimbra, Coimbra, Almedina, 1987. Todavia, segundo informação de J. R. Pita e Ana Maria Bandeira, a primeira mulher a fazer exame de Farmácia na UC, em 1860, foi Maria José Cruz de Oliveira e Silva, que é a primeira a obter o diploma de farmacêutica. 
de Medicina, matricula-se nesta escola, onde se forma em 1904. Antes da República, conclui Ferreira Gomes, depois de uma rigorosa análise documental, frequentaram a Universidade 23 mulheres, incluindo sete que seguiram o curso de parteiras ${ }^{37}$. E contava a Universidade, em 1910-1911, 1.355 alunos inscritos, dos quais só oito eram mulheres (0,59\%): quatro na Escola de Farmácia, uma na Faculdade de Filosofia, uma na de Direito (Regina Quintanilha, a primeira que virá a formar-se neste curso) e duas no curso de parteiras. Domitila de Carvalho será uma das primeiras mulheres deputadas à Assembleia Nacional do Estado Novo, na legislatura de 1935-1938, continuando na legislatura de 1938-1942.

Devemos, todavia, sublinhar que a primeira mulher que ensinou na Universidade foi-o, essa sim, na Faculdade de Letras. Trata-se, como se disse, de Carolina Michaëlis ${ }^{38}$. A primeira e única aluna da Faculdade de Letras nesse ano de 1911-1912, ao mesmo tempo que se matriculava na Faculdade de Direito, era a referida Regina Quintanilha. De resto, anotemos que 280 mulheres frequentaram a Universidade de 1910 a $1926^{39}$, embora algumas tivessem frequentado mais de um curso, o que não significa que, em qualquer caso, o tenham ou os tenham terminado. Assim, dando primazia a esta situação, ou seja, as matrículas por Faculdade, calculamos (os cálculos são nossos e não de Ferreira Gomes) que tenham frequentado a Universidade, em Letras, Direito, Medicina, Ciências, Farmácia (Escola ou Faculdade) e Escola Normal Superior, 359 mulheres (ou 306, se excluirmos a Escola Normal Superior, pois seria considerada um curso complementar), distribuídas deste modo, por ordem decrescente:

Letras, 151 (49,3\%); Ciências, 62 (20,2\%); Farmácia, 46 (15\%); Direito, 25 (8,2\%), Medicina, 22 (7,2\%).

A percentagem em relação aos homens que frequentaram a Universidade nesses anos da República não foi feita, mas parece ainda ser muito pequena. Calculamos que não chegaria a $2 \%$ (por curiosidade,

${ }^{37}$ Ferreira Gomes, ob. cit., p. 25.

${ }^{38}$ Ver Maria Manuela Gouveia Delille, Carolina Michaëlis de Vasconcelos (1851-1925). Uma alemã, mulher e erudita, em Portugal, separata da revista Biblos, Coimbra, Faculdade de Letras, LXI (1985).

${ }^{39}$ Ver Ferreira Gomes, ob. cit., cap. II. 
anotemos que em 1942-1943, ano lectivo em que se conhecem dados seguros, segundo Ferreira Gomes, num universo de 2018 aluno só $23 \%$ eram mulheres ${ }^{40}$ ). Mas é evidente que a Faculdade de Letras se ia transformando a pouco e pouco numa "escola de mulheres", seguida em importância, mas a uma grande distância, pela Faculdade de Ciências. Ou seja, o magistério era a grande meta das alunas universitárias, que iam ocupando os liceus femininos e a sua direcção, sobretudo no Estado Novo, onde divulgavam conceitos em regra conservadores ou de direita nacionalista (o mesmo, de resto, sucedia com os homens). Falámos do papel político de Domitila de Carvalho. Poderíamos acrescentar que Maria Guardiola, que se formou em Ciências (Matemática) na Universidade de Coimbra, que foi professora de liceus femininos de referência (Infanta D. Maria, em Coimbra, Carolina Michaëlis, no Porto, ou Maria Amália Vaz de Carvalho, em Lisboa) e que viria a ser deputada em quatro legislaturas (1935-1938, 1938-1942, 1942-1945 e 1949-1953), seria a primeira comissária nacional da Mocidade Portuguesa Feminina (1938).

As mulheres estarão em maioria em relação aos homens na Faculdade de Letras desde pelo menos 1940-1941 (141 homens e 190 mulheres), bem como na então Escola de Farmácia (42 homens e 63 mulheres $)^{41}$, mas ultrapassarão os homens, no cômputo geral dos alunos da Universidade, a partir de 1982-1983 (6.103 homens para 6.291 mulheres) ${ }^{42}$.

Tudo o que dissemos não significa, pois, que a presença feminina seja sinal definitivo de novas concepções sociais e culturais. Se em parte assim sucedeu, só tardiamente se poderá falar de concepções avançadas na sociedade universitária feminina. Na República, indubitavelmente, salvo raras excepções ${ }^{43}$, representaram as concepções mais conservadoras e, também no Estado Novo, no pós-guerra, ainda a mulher era interpretada fundamentalmente como "anjo do lar". Poderá, em parte, verificar-se isso pela discussão do papel da mulher na sociedade, nos anos

${ }^{40}$ Cfr. idem, p. 91.

${ }^{41} \mathrm{Cfr}$. idem.

${ }^{42}$ Cfr. idem, p. 100.

${ }^{43}$ Ver Alice Samara, Operárias e burguesas. As mulheres no tempo da República, Lisboa, A Esfera dos Livros, 2007, e Fina D'Armada, As mulheres na implantação da República, Lisboa, Ésquilo, 2010. 
cinquenta do século XX, num jornal académico de grande significado, Via Latina. Ainda se colocava o problema de saber se a mulher deveria ou não ocupar uma profissão ou se deveria preferentemente ser o pilar da ordem e do bem-estar na família. ${ }^{44}$

No entanto, é a partir dos anos cinquenta que começarão a entrar mulheres no corpo universitário, a começar na Faculdade de Letras de Coimbra, com Maria Helena Rocha Pereira, que se doutora em 1956. Noutras faculdades os doutoramentos são posteriores, sendo na Faculdade de Direito apenas nos nossos dias, em 1995.

Noutras universidades já mulheres haviam entrado anteriormente para o corpo docente, tendo sido demitida pelo Estado Novo, na leva de perseguições políticas de 1947, Andrée Crabbé Rocha, assistente da Faculdade de Letras de Lisboa, que depois do 25 de Abril de 1974 ingressará na Faculdade de Letras de Coimbra.

\section{A concluir: uma faculdade actualizada e internacionalizada?}

Durante a República, a Faculdade de Letras oscilou, pois, entre o sagrado e o profano e, independentemente da possível importância científica dos seus professores e das suas obras, como, embora conjunturalmente e de forma indirecta, e até pessoal, pretendia provar Joaquim de Carvalho, era indubitável a presença de uma grande percentagem de padres ou de católicos tradicionais, a que se vinha juntar como alunas uma significativa quantidade de mulheres, com uma formação conservadora. No seu conjunto apenas conseguimos encontrar uma mulher que se afirmou claramente nos meios democráticos, Cristina Torres dos Santos ${ }^{45}$.

\footnotetext{
${ }^{44}$ Ver o que dissemos a respeito deste tema no nosso livro A Universidade e o Estado Novo, Coimbra, MinervaCoimbra, 1999, cap. V.

${ }^{45}$ Cristina Torres dos Santos (1891-1975) foi professora, sobretudo do Ensino Técnico. Devido às perseguições de que foi vítima no Estado Novo, terminou na Figueira da Foz, sua terra natal, a viver de explicações. Começou a vida como costureira e em 1911 já era uma militante feminista, pertencendo ao Partido Republicano Português. Formou-se na Universidade de Coimbra em 1920 no curso de Ciências Histórico-Geográficas. Participou em vários congressos pedagógicos em Portugal e no estrangeiro e foi uma das mulheres mais activas da oposição, fazendo ainda parte da comissão organizadora do Congresso da Oposição
} 
Isso não significou, obviamente, também, que a Faculdade de Letras não se tornasse uma escola com ligações ao mundo, ainda que o mundo se ia tornando cada vez mais dominado por ideologias de direita. Por exemplo, é conhecida a viagem de Augusto Joaquim Alves dos Santos, que se deslocou a França (onde aprendeu com Claparède), Suíça e Bélgica, com o objectivo de estudar a forma de montar o Laboratório de Psicologia Experimental; e Joaquim de Carvalho esteve em missão de estudo em Oxford, mas só em 1930, e veio a ser doutorado honoris causa pelas Universidades de Salamanca, Montpellier e do Rio de Janeiro. Em 1924 (23 de Novembro) foram criados os cursos de férias da Faculdade de Letras e convidados grandes vultos estrangeiros para neles leccionar, no domínio da egiptologia, de estudos orientais, da história da arte, da história, etc. E no ano seguinte (Janeiro de 1925) surgia a sua revista de referência, Biblos, mas também, em 1926, o Boletim do Instituto Alemão, que duraria até 1943 e que nos anos trinta não deixou de reflectir a cultura e a propaganda nazis, mesmo na sua concepção de Universidade, mais ligada à teoria política e bélica e à tecnocracia do que ao conceito de "Universidade cultural", que seria defendido por Ortega y Gasset, na sua famosa oração Misión de la Universidad (1930). Enfim, a Faculdade de Letras de Coimbra e a Faculdade de Direito seriam dois grandes símbolos do Estado Novo e por isso não deixa de ser significativo que nas novas e actuais instalações da Faculdade de Letras, pouco depois da sua inauguração, com a presença de Salazar (22 de Novembro de 1951) ${ }^{46}$, se tenha realizado o III Congresso da União Nacional, onde Marcello Caetano defendeu, no que ficou conhecido por "discurso de Coimbra", a ideia do "Estado Novo" como um "sistema" e não como um regime ${ }^{47}$, afinal um "sistema" que durou mais de quarenta anos, sobrevivendo cerca de vinte ao fim da Segunda Grande Guerra.

Democrática de 1973. Foi atribuído o nome de Cristina Torres a uma das escolas secundárias da Figueira da Foz.

${ }^{46}$ Cfr. Maximino Correia, Ao serviço da Universidade de Coimbra. 1939-1960, Coimbra, Por ordem da Universidade, 1963, p. 169 ss.

${ }^{47}$ Cfr. Diário de Notícias, 24.11.1951. 